\title{
Chemical burn injury due to hydrofluoric acid: a case of successful management without hexafluorine
}

\author{
Hidroflorik aside bağlı kimyasal yanık hasarı: heksaflorin kullanılmadan başarı ile tedavi edilen \\ bir olgu
}

\author{
Ayten SARACOGLU, Tamer KUZUCUOGLU, Sezer YAKUPOGLU, Erhan TUNCAY, Recep DEMİRHAN
}

\begin{abstract}
We report an employee working in glass manufacturing who suffered a burn, induced by hydrofluoric acid (HF) as a result of an explosion of an acid container. The patient was admitted to our burn center with second and third degree burn injuries over $5 \%$ of his body. His burn injuries improved dramatically without applying hexafluorine. The primary goal of all treatment modalities is to prevent deep tissue injury, decomposing fluoride ion chemically. In the treatment of such burns, the wound area should be washed with plenty of water, preferably with bottled water. In addition, the compounds of calcium and magnesium applied topically and hexafluorine have a role in the treatment, where available. Training programs, including first-aid teams, should be prepared for this in order to reduce or prevent the mortality and morbidity associated with HF burns.
\end{abstract}

Keywords: Hydrofluoric acid, Burns, Hexafluorine

\footnotetext{
Ayten Saracoglu (西)

Department of Anesthesiology and Reanimation, School of Medicine, Bilim University, Istanbul, Turkey

e-mail: anestheziayten@gmail.com

Tamer Kuzucuoglu, Sezer Yakupoglu

Anesthesiology and Reanimation Clinic, Kartal Dr. Lütfi Kurdar Training and Research Hospital, Istanbul, Turkey

Erhan Tuncay

General Surgery Clinic, Kartal Dr. Lütfi Kırdar Training and Research Hospital, Istanbul, Turkey

Recep Demirhan

Thoracic Surgery Clinic, Kartal Dr. Lütfi Kırdar Training and Research Hospital, Istanbul, Turkey
}

Submitted/Gönderme: 07.03.2015

Accepted/Kabul: 27.05.2015

\section{ÖZET}

$\mathrm{Bu}$ yazımızda, cam imalat sanayisinde çalışan bir işçinin elindeki asid bidonunun patlamasıyla gelişen hidroflorik aside bağlı yanık hasarlı hastamızı sunduk. Hasta, yanık merkezimize vücudunun $\% 5$ 'inde oluşan 2 . ve 3 . derece yanık hasarı ile başvurdu. Hasta merkezimize süratle ulaştırıldığ 1 için hastanın yanık hasarı heksaflorin uygulanmadan tamamen iyileşti. Tüm tedavi yöntemlerinin temel amac1, florid iyonunu kimyasal olarak ayrıştırarak derin doku hasarını önlemektir. Bu tür yanıkların tedavisinde hasarlı alan bolca suyla y1kanmalı, mümkünse içme suyu tercih edilmelidir. Topikal uygulanabilen kalsiyum ve magnezyum bileşikleri ve bulunabildiği sürece heksaflorinin tedavide yeri vardır. Hidroflorik asid yanıklarının önlenebilmesi için ilk yardım ekiplerinin de içinde bulunduğu eğitim programlarının düzenlenmesi mortaliteyi ve morbiditeyi azaltacağ düşüncesindeyiz.

Anahtar kelimeler: Hidroflorik asid, Yanık, Heksaflorin

\section{Introduction}

Hydrofluoric acid (HF) is a strong inorganic acid, and often used at concentrations of 49 to $70 \%$. The hydrogen ions are responsible for the development of skin corrosion. Fluoride ions are responsible for systemic poisoning, and cardiovascular collapse, because they bind to serum calcium and magnesium, entering the circulatory system from the skin and giving rise to the release of potassium from red blood cells [1]. Although, the type of burn that is induced by HF appears rarely, it is characterized by serious lesions. This chemical agent, which can be found in the workplace as well as in the home is used for the production of high-octane gasoline, glass, in the tanning industry in rust removal procedures, for the production of laundry detergents and for controlling the fermentation process in breweries [2]. 
Unlike other acid burns, it can lead to tissue necrosis and bone destruction [3]. In the treatment of such burns, the wound area should be washed with plenty of water, preferably with bottled water. In addition, the compounds of calcium and magnesium applied topically and hexafluorine have a role in the treatment [4]. This paper reports an employee working in glass manufacturing who experienced a HF-induced burn as a result of an explosion of an acid container he had in his hands. Because he presented to our burn center expeditiously his burn improved completely and dramatically without any application of hexafluorine.

\section{Case Report}

A 31-year-old the American Society of Anesthesiologists (ASA I) male patient who was working in glass manufacturing industry, presented to our burn unit. $\mathrm{He}$ had a HF burn caused by the explosion of a 5-liter acid container. On physical examination, it was found that the affected clothing had not been removed from the patient and that he had not been washed with water. The patient presented to our hospital burn unit an hour after the incident. It was observed that, based on the Lund-Browder chart [ ], second and third degree burns occurred in $5 \%$ of his body. The lesions induced by the HF burn on the left forearm and the trunk were immediately cleaned with plenty of water, then his clothes were removed and cleaning with water was continued (Figure 1).

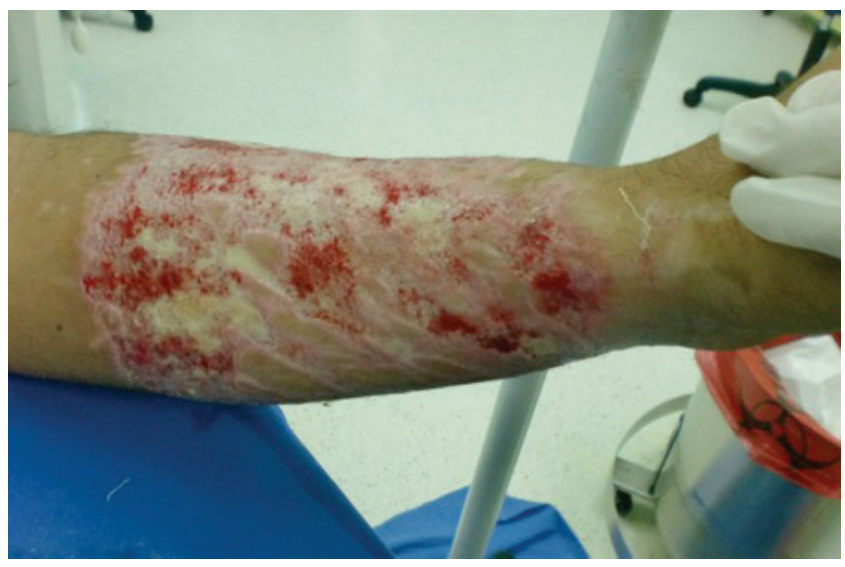

Figure 1. The lesions induced by hydrofluoric acid burn in the left forearm

A topical gel of calcium gluconate $(2.5 \%)$ was used simultaneously. Central catheterization, invasive blood pressure and routine monitorization were performed in the burn intensive care unit. Although he was hemodynamically stable and in sinus rhythm on the ECG, biochemical laboratory findings showed deep hypocalcaemia, so an IV infusion of $40 \mathrm{ml}$ of $10 \%$ calcium gluconate in $500 \mathrm{ml}$ of $0.9 \%$ saline was started. The solution was infused over a 24-hour period. Then the calcium level of the patient was monitored until the $48^{\text {th }}$ hour. His mean arterial pressure was in the range of 65 to $85 \mathrm{mmHg}$, heart rate was 80 to 100 beats/min and respiratory rate was between 9 to $12 /$ $\min$. Ionize calcium was $0.53 \mathrm{mmol} / \mathrm{L}$ before the treatment. The potassium level remained within the range of 3.4 to 3.9 $\mathrm{mEq} / \mathrm{L}$. The concentration of sodium in the serum was in the range of 137 to $142 \mathrm{mEq} / \mathrm{L}$, chloride was 98 to $106 \mathrm{mEq} / \mathrm{L}$ and magnesium was $1.1 \mathrm{mg} / \mathrm{dL}$. Analgesia was achieved by multimodal analgesia in which intravenous opioid agents were combined with non-steroidal anti-inflammatory drugs. The patient was dressed with warm water in a washing room under sedation. No hexafluorine solution was applied because it was not available. No fasciotomy was done, as compartment development was not noted. The patient was transferred to the burn unit where his hypocalcaemia recovered uneventfully within 24 hours. No adverse effect developed during these procedures. The lesions were stable at the end of the first week and radiologic imaging showed no abnormality of the bone. For skin grafting, the patient was referred to the department of plastic and reconstructive surgery.

\section{Discussion}

Different treatment options have been suggested for HF burns. The primary goal of all treatment modalities is to prevent deep tissue injury by decomposing fluoride ion [5]. The first step is to wash the burn lesions with plenty of water, preferably with bottled water.

A second goal is to transform free fluoride ions into insoluble fluoride salts. A $2.5 \%$ calcium gluconate gel is often used to treat burn lesions induced by acid $[6,7]$. After first aid by washing and application of gel, $5 \%$ of calcium gluconate injections may be required for lesions especially of deep burns with a large surface area [5]. Severe systemic toxicity may occur following HF burns. Wu et al. [8] reported successful resuscitation of a case developing systemic toxicity, including hypomagnesemia, hypokalemia, hypocalcemia, bradycardia, and cardiac arrest with IV calcium, magnesium and potassium. The case abruptly developed cardiac arrest at the 16th hour after contact with the agent, despite $3 \%$ of total body surface area (TBSA) suffer first-degree burns. The TBSA of our patient's burn was greater and the degree of the burn was higher than the 
patient's burn that $\mathrm{Wu}$ et al. reported, however, its course was not fatal. This demonstrates that treatment should be planned carefully and started urgently independent of the size of the lesion. HF-induced burns treated ineffectively or late may have catastrophic consequences even if they are minor injuries [9]. Sudden death has been reported due to multi-organ failure, severe cardiac arrhythmias or ventricular fibrillation $[10,11]$. There have been reports of HF-induced burns due to causes other than contact. An example may be an exposure via inhalation; in which case, laryngeal edema should be excluded or treated promptly by performing fiber optic laryngoscopy. Inhalation of 3\% calcium gluconate should be simultaneously added to the treatment [12]. Ingestion of batteries or magnets is another cause for injuries by HF [13]. Although, dermal exposure is mostly limited to moderate irritation or invasion, burns caused by inhalation or ingestion often manifest themselves with more serious systemic complications. It is also essential to neutralize the acid with water or milk and also to perform gastric lavage using a solution of calcium gluconate in the emergency treatment [14].

Hexafluorine solution should also be used in HF burn patients. This solution is a decontaminating solution forming hypertonic, amphoteric and chelating actions. Specifically, it causes deactivation of hydrogen ions and forms chelates with fluoride ions. HF may cause progressive destruction of tissue which can include bone injury. Because even the exposure of a $1 \%$ solution of this chemical can cause serious systemic symptoms, hexafluorine is recommended for use as early as possible [15]. However, in the absence of hexafluorine, calcium gluconate solutions are compulsorily used in emergency situations.

Soderberg et al. [16] gave hexafluorine to 16 patients with ocular or dermal HF burns, who presented to their departments within one year. The progress of the lesions was successfully kept under control in $75 \%$ of cases, and the mean hospital observation time was decreased to less than one day for $44 \%$ of the patients. Burgher et al. [17] decribed that no histological lesions were present in patients who had been washed with only hexafluorine in the early period after exposure, and compared this with patients to whom water plus topical calcium gluconate had been applied in an experimental setting. However, in a study of rats, Hulten et al. [18] investigated blood calcium, potassium, and ionized fluoride levels in groups whose burn lesions were washed with hexafluorine solution, with water alone or with water + $2.5 \%$ calcium gluconate, however, they could not prove that hexafluorine is more effective than the other two treatments.
Hexafluorine was not available for our patient. We primarily treat burn lesions with topical calcium gluconate gel and then initiate systemic therapy. At this stage, the use of hexafluorine solution could have had a positive effect on the treatment. However, we assumed that taking the patient to our burn center within 1 hour had also a positive impact on the prognosis. We considered the factors that play a negative role in the availability of this agent. These included the infrequent occurrence of this type of burn than of others, and the fact that hexafluorine solution is expensive and is not being used widely.

However, the agent should be routinely used by hospitals as its benefits have been proven. Because its shelf life is two years and it can be stored easily, hexafluorine solution must be available in workplaces at high risk of HF burns, and should be immediately applied to the whole body upon exposure. The later the implementation of this agent, the longer the length of hospitalization and the higher the number of additional complications, such as the signs of systemic toxicity [16].

We believe that training programs, including first-aid programs should be planned from this point of view. Thus, the mortality and morbidity associated with HF burns could be prevented.

\section{Conflict of interest statement}

The authors had no financial and personal relationships with other people or organisations that could inappropriately influence (bias) their work.

\section{References}

1. Yoshimura CA, Mathieu L, Hall AH, Monteiro MG, de Almeida DM. Seventy per cent hydrofluoric acid burns: delayed decontamination with hexafluorine and treatment with calcium gluconate. J Burn Care Res 2011;32:149-54. doi: 10.1097/ BCR.0b013e31822240f7.

2. Hatzifotis M, Williams A, Muller M, Pegg S. Hydrofluoric acid burns. Burns 2004;30:156-9. doi: 10.1016/j.burns.2003.09.031.

3. Dünser MW, Ohlbauer M, Rieder $\mathrm{J}$, et al. Critical care management of major hydrofluoric acid burns: a case report, review of the literature, and recommendations for therapy. Burns 2004;30:391-8. doi: 10.1016/j.burns.2004.01.005.

4. ANSI. ANSI/ISEA Z358.1-2009 American National 
Standard for Emergency Eyewash and Shower Equipment. International Safety Equipment Association, Arlington, Virginia, September 14, 2009.

5. Ozcan M, Allahbeickaraghi A, Dündar $\mathrm{M}$. Possible hazardous effects of hydrofluoric acid and recommendations for treatment approach: a review. Clin Oral Investig 2012;16:15-23. doi: 10.1007/s00784011-0636-6.

6. Aguilera IM, Vaughan RS. Calcium and the anaesthesist. Anaesthesia 2000;55:779-90.

7. Yamashita M, Suzuki M, Hirai $H$, Kajigaya $H$. Iontophoretic delivery of calcium for experimental hydrofluoric acid burns. Crit Care Med 2001;29:1575-8.

8. $\mathrm{Wu}$ ML, Deng JF, Fan JS. Survival after hypocalcemia, hypomagnesemia, hypokalemia and cardiac arrest following mild hydrofluoric acid burn. Clin Toxicol (Phila) 2010;48:953-5. doi: 10.3109/15563650.2010.533676.

9. Summers A. Treating burns caused by hydrofluoric acid. Emerg Nurse 2011;19:12-5; quiz 17. doi: 10.7748/ en2011.06.19.3.12.c8553.

10. Barillo DJ, Cancio LC, Goodwin CW. Treatment of whitephosphorus and other chemical burn injuries at one burn center over a 51-year period. Burns 2004;30:448-52. doi: 10.1016/j.burns.2004.01.032.

11. Sheridan RI, Ryan CM, Duinby Jr WC, Blair J,
Tompkins RG, Burke JF. Emergency management of major hydrofluoric acid exposures. Burns 1995;21:62-4.

12. Lee DC. Treatment of inhalation exposure to hydrofluoric acid with calcium gluconate. J Occup Med 1993;35:47.

13. Salzman M, O’Malley RN. Updates on the evaluation and management of caustic exposures. Emerg Med Clin North Am 2007;25:459-76. doi: 10.1016/j. emc.2007.02.007.

14. Schiettecatte D, Mullie G, Depoorter M. Treatment of hydrofluoric acid burns. Acta Chir Belg 2003;103:375-8.

15. Hall AH, Blomet J, Gross M, Nehles J. Hexafluorine for emergent decontamination of hydrofluoric acid eye/skin splashes. Semiconductor Safety Assoc J 2000;14:30-33.

16. Soderberg K, Kuusinen P, Mathieu L, Hall AH. An improved method for emergent decontamination of ocular and dermal hydrofluoric acid splashes. Vet Hum Toxicol 2004;46:216-8.

17. Burgher F, Mathieu L, Lati E, et al. Part 2. Comparison of emergency washing solutions in $70 \%$ hydrofluoric acid-burned human skin in an established ex vivo explants model. Cutan Ocul Toxicol 2011;30:108-15. doi: 10.3109/15569527.2010.534748.

18. Hultén P, Höjer J, Ludwigs U, Janson A. Hexafluorine vs. standard decontamination to reduce systemic toxicity after dermal exposure to hydrofluoric acid. J Toxicol Clin Toxicol 2004;42:355-61. 